Article

\title{
Characterization and Testing of a Novel Sprayable Crosslinked Edible Coating Based on Salmon Gelatin
}

\author{
Cielo Char, Cristina Padilla, Vanessa Campos, Marzena Pepczynska, Paulo Díaz-Calderón and \\ Javier Enrione * (D)
}

Biopolymer Research \& Engineering Laboratory (BIOPREL), School of Nutrition and Dietetics, Faculty of Medicine, Universidad de los Andes, Santiago 2100000, Chile

* Correspondence: jenrione@uandes.cl

Received: 4 August 2019; Accepted: 17 September 2019; Published: 20 September 2019

\begin{abstract}
The aim of this study was to develop and characterize a sprayable edible coating using salmon gelatin (SG) and its stabilization by photopolymerization using riboflavin (Rf). Suspensions of SG with Rf at $\mathrm{pH}$ values of 5.0 and 8.5 were exposed for $2 \mathrm{~min}$ to visible light (VL) and ultraviolet (UV) light and further characterized to determine structural changes of the different gelatin formulations. Rheology analysis showed that at $\mathrm{pH} 5$, the loss modulus $\left(G^{\prime \prime}\right)$ was higher that the storage modulus $\left(G^{\prime}\right)$ for crosslinked samples (VL and UV light). However, at $\mathrm{pH} 8.5 G^{\prime}$ values increased over $G^{\prime \prime}$, showing a strong crosslinking effect. Interestingly both moduli did not intersect at any point and their maximum values did not change upon cooling with respect to the gelatin suspension without light exposure, demonstrating that triple helix formation was not affected by the reaction. In fact, neither the gelation temperature nor the enthalpy values were significantly affected. Viscosity measurements confirmed the hydrogel formation using $\mathrm{VL}$, showing higher viscosity values after exposure at increasing temperatures. Transmittance $(T \%)$ measurements showed an increase in $T \%$ in the suspensions after VL exposure, with only a $10 \%$ decrease compared to SG without riboflavin. For validation, the coating was sprayed in fresh salmon fillets, showing a 37\% delay in spoilage and reduced weight loss. Therefore, photopolymerization of low viscosity gelatins would allow to manage viscoelasticity of the biomaterial stabilizing it as coating and preventing the deterioration of salmon fillets.
\end{abstract}

Keywords: low viscosity gelatin; cross-linking; hydrogel; riboflavin; visible light; UV light

\section{Introduction}

Gelatin is a versatile biomaterial with a wide range of industrial applications that include the fields of pharmacy, food science and biomedicine, among others [1,2]. Specifically, in the case of the food industry, it is mainly used as a food ingredient to provide viscoelastic and emulsifying properties as well as a clarification agent or protective structuring material as edible coating [2-4]. Gelatin is obtained through the hydrolysis of collagen fibers extracted from skin, cartilage, and bones and/or hair of animals [1]. The most commonly used commercial gelatins are derived from cattle and pigs.

In food applications, literature shows that gelatin has been also widely investigated in the field of edible coatings due to its excellent film-forming properties, high processability and non-toxicity $[3,5,6]$. Also, it has been described as an effective barrier against oxygen and to reduce moisture loss during storage [3,7]. Gelatin edible coatings have been applied mostly by dipping or in the form of rigid films [8-10].

In order to improve the physico-chemical properties and functionality of gelatin based coatings, several studies have attempted to evaluate the effect of the addition of different elements such as plasticizers or active compounds with antioxidant, antimicrobial, or hydrophobic properties [11-16]. 
Also, the combination of gelatin with other biopolymers with different characteristics, such as starch [17], soy protein [18], chitosan [19], cellulose [20], and different crosslinking methods [21,22] have been studied in order to improve its mechanical and transport properties.

In recent years, there has been an increased interest in the production of gelatin from marine sources due to risks of transmitting pathogen vectors such as prions (i.e., bovine spongiform encephalopathy) and to religious restrictions related to porcine and bovine products [23-25]. Gelatin from different marine species such as salmon, tuna, carp, cod, and eel have been successfully produced and characterized [23,26-30]. More specifically, gelatin from cold water species have shown significant differences compared to those produced from mammals, in terms of thermal, rheological, viscoelastic, and mechanical properties [29,31-33]. Gelatin extracted from salmon skin has shown low viscosity and melting temperature [23,29]. This has been related to the biological adaption of this species to its low temperature environment $[12,31,32]$, featuring a collagen structure with lower concentration of the amino acids proline and hydroxyproline, and lower molecular weight of protein alfa chains [29]. These characteristics offer the potential of a wider temperature processing window at low viscosity, presenting the potential to develop high value commercial applications, such as a sprayable edible coating for shelf life extension of different fresh foods stored under refrigeration conditions $\left(<8^{\circ} \mathrm{C}\right)[12]$.

An important feature required for an edible coating is its structural integrity on the surface of the food. This is even more important in the case of a low viscosity solution. A suitable strategy for structural stabilization is polymer crosslinking. Different approaches have been described in the literature, such as chemical crosslinking, i.e., using glutaraldehyde [34,35], genipin [35], formaldehyde [21,36], and 1-Ethyl-3-(3-dimethylaminopropyl)carbodiimide (EDS) [37]. Other methods include chemical modification of gelatin such as addition of methacryloyl side groups (GelMA) that can form photopolymerized hydrogels using ultraviolet light in the presence of a synthetic photoinitiator (e.g., Irgacure 2959) [38,39]. Although these approaches have shown good results by fine tuning of mechanical properties in gelatin hydrogels, they are aimed to biomedical applications such as tissue engineering [38,39]. Limitations in their use as edible coating arise from the chemicals used for functionalization and free radical generation for the protein stabilization, which have not been authorized for human consumption. Enzymatic crosslinking using transglutaminase has also been investigated as a safer alternative [21,40]. However, limitations related to cross-linking and stabilization kinetics and more importantly, the high cost of enzymes, limits their use at a larger scale. Therefore, a safer, low cost and more responsive gelatin crosslinking method would be valuable to be explored. An alternative that have shown potential is the use of riboflavin as a photoinitiator in combination with ultraviolet (UV) light. This compound is a vitamin (also known as vitamin B2) that has shown minimal cytotoxicity [41,42]. Also, it is classified as generally recognized as safe (GRAS) by the US Food and Drug Administration (FDA). This approach has been investigated mainly for the development of biomaterials for tissue engineering, where collagen type I or gelatin are crosslinked in the presence of riboflavin and UV light through a free radical reaction [41-45]. Moreover collagen Type I has been successfully crosslinked with riboflavin in the presence of a $475 \mathrm{~nm}$ light source, producing stable scaffolds with favorable cell survival [46]. Since riboflavin is also chemically sensitive under the visible spectrum of light, low viscosity gelatin-based hydrogels could be developed under safer conditions, generating a stable sprayable edible coating to reduce fresh food spoilage.

The aim of this study was to develop and characterize a sprayable edible coating using salmon gelatin (SG) and riboflavin (Rf) to be crosslinked by visible light (VL). UV light was also tested for hydrogel formation for comparison purposes. In order to validate this coating to preserve microbial stability and quality parameters, fresh salmon fillets were used during cold storage. This process could be beneficial for the salmon industry in two ways since salmon gelatin could be extracted from its by-products contributing to a more sustainable business but also applied onto fresh salmon fillets directly on the process line differentiating from conventional coating methods that are mainly achieved by dipping. 


\section{Materials and Methods}

\subsection{Materials}

Atlantic salmon (Salmo salar) skins and fillets were kindly provided by a local producer. Sodium hydroxide $\geq 99.0 \%$ and glacial acetic acid 100\% were purchased from Merck (Darmstadt, Germany). (-)-Riboflavin 98\% was purchased from Sigma-Aldrich, Inc. (St. Louis, MO, USA).

\subsection{Salmon Gelatin Production}

Salmon gelatin (SG) was extracted from the skins following the protocol proposed by Díaz-Calderón et al. [29], with some modifications. Salmon skins previously stored at $-20{ }^{\circ} \mathrm{C}$ were thawed at $10{ }^{\circ} \mathrm{C}$ and cleaned to eliminate all residues of muscle and scales and then cut into squared pieces of approximately $3 \mathrm{~cm}^{2}$. A series of pretreatments were carried out to eliminate impurities. First, the skins were submerged in $0.1 \mathrm{M} \mathrm{NaOH}$ solution, which was stirred at constant speed at $10^{\circ} \mathrm{C}$ for $1 \mathrm{~h}$. Then, they were washed with distilled water and the process was repeated once again at the same conditions. After washing, the pieces of salmon skin were submerged into a $0.05 \mathrm{M}$ acetic acid solution and stirred at constant speed at $10^{\circ} \mathrm{C}$ for $1 \mathrm{~h}$. The gelatin extraction process was carried out at $60^{\circ} \mathrm{C}$ and $\mathrm{pH} 4$ for $4 \mathrm{~h}$. Glacial acetic acid was used to adjust and controlling $\mathrm{pH}$ during the extraction. The supernatant liquid was vacuum filtered using paper filters $(22 \mu \mathrm{m})$ and dried at $60{ }^{\circ} \mathrm{C}$ during $72 \mathrm{~h}$ in a forced convection oven (WOF-105, WiseVen, Seoul, Korea). The dried gelatin was hermetically sealed and stored at $4{ }^{\circ} \mathrm{C}$ until further use.

\subsection{Effect of $p H$ on Riboflavin Absorbance Spectrum}

With the aim to determine the best conditions for riboflavin to react as a photoinitiator, the effect of $\mathrm{pH}$ on the absorbance spectrum was assessed. The absorption spectrum of riboflavin was determined under UV and visible light (VL) (210-550 nm) using a spectrophotometer (UV-1800, Rayleigh, NC, USA). Riboflavin suspensions in water were adjusted to different pH values (5.0, 8.5, and 10.0) in order to evaluate the relationship between $\mathrm{pH}$ and riboflavin reactivity with different wavelengths. The suspensions were loaded into a $3 \mathrm{~mL}$ quartz cuvette. The dilution of the sample was adjusted according to the spectrum obtained, in order to not exceed 4.0 absorbance integers. The measurements were carried out at least in duplicate.

\subsection{Preparation of Salmon Gelatin-Riboflavin (SG-Rf) Suspensions}

Gelatin suspensions were prepared by dissolving SG $10 \% w / v$ in water at $60{ }^{\circ} \mathrm{C}$ under constant agitation for $1 \mathrm{~h}$, then an amount of riboflavin to reach a final concentration of $0.025 \% w / v$ was added. Based on the absorbance data generated from Section 2.3, the suspensions were cooled down to room temperature and the samples prepared at 5.0 or $\mathrm{pH}$ 8.5. During the preparation of the samples for all the tests, the solutions added with riboflavin were protected from the light.

\subsection{Preparation of Salmon Gelatin-Riboflavin Hydrogels}

The hydrogels were produced by exposing the SG-Rf suspensions (both at pH 5.0 or 8.5) to UV (S2000-XLA 365nm, Omnicure series 2000, Lumen Dynamics, Mississauga, ON, Canada) or visible light (VL) (Cool Cure Series, Special 450nm, Lesco, Lebanon, IN, USA). The probes were placed at $4 \mathrm{~cm}$ from the surface of the suspensions for 2 min exposure.

\subsection{Characterization of Salmon Gelatin-Riboflavin Hydrogels}

\subsubsection{Viscoelastic Behavior}

The viscoelastic characterization was performed using a rheometer (Discovery HR-2, TA Instruments, New Castle, DE, USA). Oscillation tests were performed using a flat geometry of $50 \mathrm{~mm}$ in diameter with a gap of $300 \mu \mathrm{m}$. Before each measurement, $600 \mu \mathrm{L} \mathrm{SG-Rf}$ at pH 5.0 and 
8.5 were exposed to UV or VL in-situ on the base of the rheometer. The control samples were not exposed to light. A strain of $10 \%$, frequency of $1 \mathrm{~Hz}$ and temperatures from 40 to $-5{ }^{\circ} \mathrm{C}$ at a cooling speed of $3{ }^{\circ} \mathrm{C} / \mathrm{min}$, and from -5 to $40{ }^{\circ} \mathrm{C}$ at the heating rate of $3{ }^{\circ} \mathrm{C} / \mathrm{min}$ were applied. For control (non-crosslinked) samples, the gelling temperature $\left(T_{\text {gel }}\right)$ and melting temperature $\left(T_{\mathrm{m}}\right)$ were determined from the point of convergence between the storage modulus $\left(G^{\prime}\right)$ and the loss modulus $\left(G^{\prime \prime}\right)$ in the corresponding curve. All the measurements were carried out at least in duplicate.

\subsubsection{Apparent Viscosity}

Based on the data produced as in Section 2.6.1, the viscosity of the samples during cooling, were determined using the rheometer (Discovery HR-2, TA Instruments, New Castle, DE, USA) and geometry (flat of $50 \mathrm{~mm}$ diameter) and a gap of $300 \mu \mathrm{m}$. Before each measurement, $600 \mu \mathrm{L}$ of the sample (SG-Rf pH 8.5) were exposed for 2 min with VL directly on the base of the rheometer. The control samples were not exposed to the light. The temperature sweeps were assessed in a range from 25 to $-5{ }^{\circ} \mathrm{C}$, using a shear rate of $100 \mathrm{~s}^{-1}$ and a cooling speed of $3{ }^{\circ} \mathrm{C} / \mathrm{min}$. Each sample was measured at least in duplicate.

\subsubsection{Thermal Properties}

Thermal properties of the SG-Rf ( $\mathrm{pH}$ 8.5) hydrogels exposed to VL and the unexposed control were determined by Differential Scanning Calorimetry (DSC). Approximately $70 \mathrm{mg}$ of each sample (SG-Rf adjusted to $\mathrm{pH}$ 8.5) were loaded into aluminum pans of $100 \mu \mathrm{L}$ and exposed to VL for $2 \mathrm{~min}$. The control samples were not exposed to light. The samples were subject to thermal scans using a DSC-1 (Mettler-Toledo, Greifensee, Switzerland). Prior performing the measurements, the DSC was calibrated using indium $\left(T_{\mathrm{m}}=156.6 \pm 1.56^{\circ} \mathrm{C}\right.$ and melting enthalpy $\left.\Delta H=28.55 \pm 1 \mathrm{~J} / \mathrm{g}\right)$. An empty pan was used as a reference. All the experiments were performed in triplicate using the following thermal profile: Heating to $60^{\circ} \mathrm{C}$ at $10^{\circ} \mathrm{C} / \mathrm{min}$ to erase the samples thermal history, holding at $60^{\circ} \mathrm{C}$ for $5 \mathrm{~min}$, cooling from 60 to $-10^{\circ} \mathrm{C}$ at $3{ }^{\circ} \mathrm{C} / \mathrm{min}$, holding at $-10^{\circ} \mathrm{C}$ for $5 \mathrm{~min}$. The gelling temperature $\left(T_{\text {gel }}\right)$ was determined as the onset of the exothermic peak on the cooling curve. While, changes in gelling enthalpy $\left(\Delta H_{\text {gel }}\right)$ was calculated as the area under the peak and calculated on a dry base. The curves were analyzed using the STARe software (DB V 12.10).

\subsubsection{Light Transmittance}

The optical properties of the hydrogels were evaluated as the change in transmittance $(T \%)$ between samples (SG-Rf at $\mathrm{pH}$ 8.5) exposed to VL for $2 \mathrm{~min}$ and the control with no light exposure. Additionally, SG without riboflavin was also evaluated as a reference. $T \%$ was quantified at the visible wavelength range (400-700 nm) using a spectrophotometer (UV1800 V/VIS, Rayleigh, Beijing, China). A volume of $1 \mathrm{~mL}$ of each sample was loaded into a $1.5 \mathrm{~mL}$ plastic cuvette and then exposed for $2 \mathrm{~min}$ at a distance of $4 \mathrm{~cm}$ from the lateral face. The samples were analyzed at least in duplicate.

\subsection{Evaluation of Salmon Gelatin-Riboflavin Hydrogels as a Sprayable Edible Coating}

\subsubsection{Coating of Salmon Fillets}

Frozen salmon (Salmo salar) fillets with skins on one side were thawed at $4{ }^{\circ} \mathrm{C}$ and sized to pieces of $4 \mathrm{~cm}^{2}$ in a cool room $\left(10^{\circ} \mathrm{C}\right)$. The coating was prepared with SG $(10 \% w / v)$ added with $0.025 \% w / v \mathrm{Rf}$ and adjusted to $\mathrm{pH} 8.5$ following the same procedure commented before (Section 2.4). The suspension was sprayed onto the salmon fillets using an air compressor (Huracan 1520, Indura, Santiago, Chile) with a $1.5 \mathrm{~mm}$ diameter spray nozzle. The coated fillets were exposed to VL (at a distance of $4 \mathrm{~cm}$ from the surface) for $2 \mathrm{~min}$. Each fillet piece was placed into hermetic plastic boxes and stored at $2 \pm 0.5^{\circ} \mathrm{C}$ for 14 days. Untreated salmon fillets were stored under similar conditions and used as control. 


\subsubsection{Weight Loss of Salmon Fillets}

The moisture loss of the samples was determined from changes in weight over the storage time. Each fillet piece (coated and control) was stored at $2 \pm 0.5{ }^{\circ} \mathrm{C}$ into hermetic plastic boxes for 14 days. The weight of the samples was registered on the days 0,7 , and 14 after processed. The pieces were weighted using an analytical balance with an accuracy of $0.1 \mathrm{mg}$ (AUX120, Shimadzu, Japan). Each treatment was evaluated in triplicate.

\subsection{3. $\mathrm{pH}$ Evolution of Salmon Fillets}

The $\mathrm{pH}$ of the samples (coated and control) was monitored using a flat surface $\mathrm{pH}$ electrode GL42 (Gondo Electronic Co., Taipei City, Taiwan) and a 6177 pH/ORP pHmeter (Jenco Instruments, Shanghai, China). The measurement was performed on the fillet surface. The $\mathrm{pH}$ was registered on the days 0,4 , 6,8 , and 13 after processed. Each treatment was evaluated with four replicates.

\subsubsection{Color Evolution of Salmon Fillets}

The color parameters of samples (coated and control fillets) were determined using a colorimeter CR-410 (Konica Minolta, Tokyo, Japan). The color parameters L* (clarity), $a^{*}$ (red-green component) and $\mathrm{b}^{*}$ (yellow-blue component) were recorded on days 0 and 13. Each treatment was evaluated with four replicates. The total color difference CIE $\Delta E 2000\left(\Delta E_{00}\right)$ was calculated following the equations reported by Sharma et al. [47].

\subsubsection{Microbial Stability of Salmon Fillets}

Fillet pieces (coating and control) were taken from cold storage at days 0, 4, 6, 8, 11, and 13 after processed and the total aerobic mesophilic counts were determined as follows: $10 \mathrm{~g}$ fillet samples were aseptically cut and homogenized with $90 \mathrm{~mL}$ of $0.1 \%$ peptone water in a paddle blender stomacher (Interscience, Saint Nom, France) for $1 \mathrm{~min}$. The dilution and inoculation process were carried out according to ISO 4833-1 [48]. Agar plate count was used to obtain the total aerobic mesophilic counts which were incubated at $30^{\circ} \mathrm{C}$ for $48 \mathrm{~h}$. The colonies were enumerated and plotted as log CFU/g vs time. Determinations were done with four replicates.

Finally, the microbial growth data were modelled by means of the reparametrized modified Gompertz equation (Equation (1)) [49,50] using Solver tool for Excel (Microsoft Office ProPlus 365, Redmond, WA, USA).

$$
\ln \frac{N}{N_{0}}=A \cdot \exp \left\{-\exp \left[\frac{\mu_{m} \cdot e}{A} \cdot(\lambda-t)+1\right]\right\}
$$

where the three phases of the growth curve can be described by the following parameters: Maximum specific growth rate $(\mu \mathrm{m})$, given by the slope of the line of the exponential growth zone observed in the logarithmic curve of the number of microorganisms; lag time $(\lambda)$, defined as the intersection of the tangent of the exponential growth zone to the $x$-axis; the asymptote $A\left(A=\ln N_{\infty} / N_{0}\right)$, which corresponds to the maximal value reached (Zwietering et al. [49]; Pina-Perez et al. [50]). Furthermore, in order to simplify the analysis, the parameter $A$ was recalculated as $\log N_{\infty} / N_{0}$ to represent the microorganisms growth cycles reached in each treatment. The adequacy of growth model was examined by adjusted determination coefficients $\left(R^{2} a d j\right)$ and Root Mean Standard Error (RMSE).

\subsubsection{Statistical Analysis}

Data is presented as the mean \pm standard deviation (SD). Differences were analyzed using Analysis of variance (ANOVA) and Fisher's least significant difference test (LSD) with a 95\% confidence level, using the software Statgraphics Centurion XVI (StatPoint Tecnologies Inc., Warrenton, VA, USA). 


\section{Results and Discussion}

\subsection{Effect of $p H$ on Riboflavin Absorbance Spectrum}

The UV-visible light spectrums for the absorbance of aqueous riboflavin suspensions adjusted to different $\mathrm{pH}$ values are displayed in Figure 1. The spectrums show that the chemical structure of this vitamin absorbed light under the UV range with a peak near to $365 \mathrm{~nm}$, but also absorbed under the visible range with a peak close to $450 \mathrm{~nm}$, which corresponds to the wavelength of the visible light (VL, color blue). This could imply that the crosslinking reaction of gelatin with riboflavin could be developed not only by photopolymerization with UV light but also with VL, with the advantage of a safer process operation. In accordance to our results, an experimental and a modeled absorption spectrum of riboflavin in water has been previously reported, with major absorbance peaks at $444 \mathrm{~nm}$ and $365 \mathrm{~nm}$ [51].

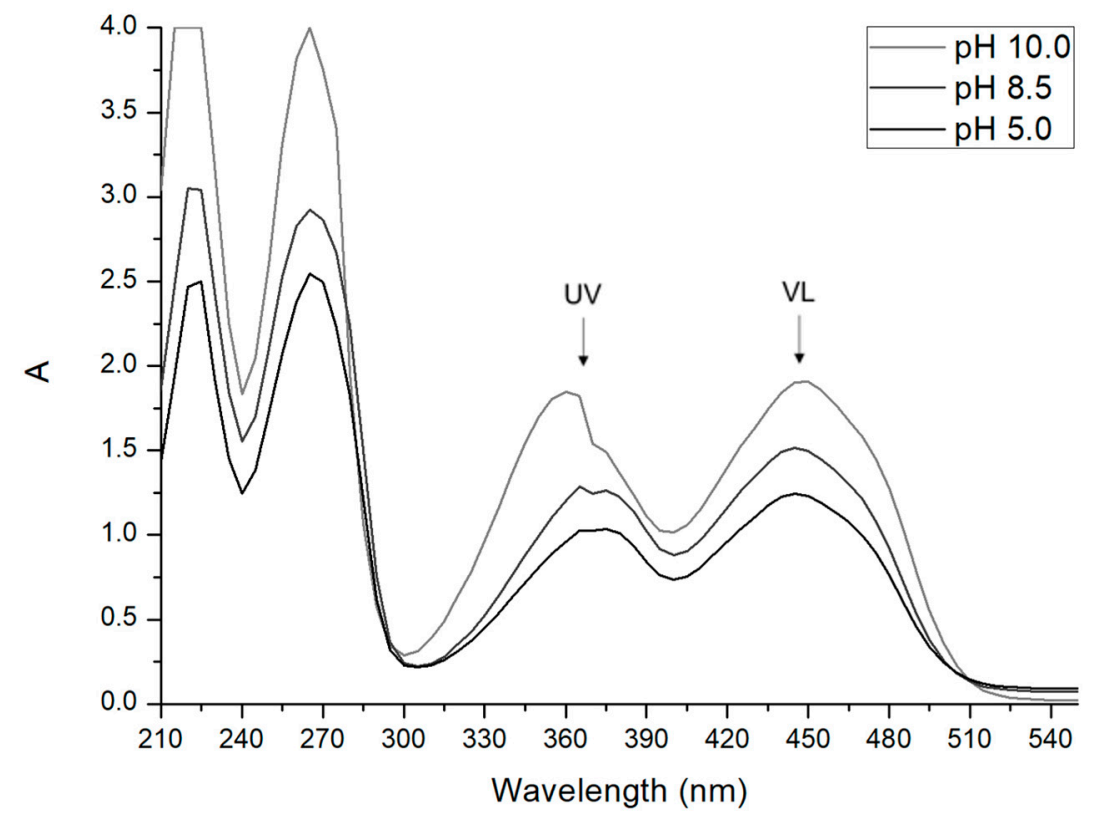

Figure 1. Riboflavin absorbance spectrum $(210-550 \mathrm{~nm})$ at different $\mathrm{pH}$ values. Wavelength values of $365 \mathrm{~nm}$ (UV light) and $450 \mathrm{~nm}$ (Visible light) are indicated with arrows.

The intensity of the absorbance peaks increased when the $\mathrm{pH}$ was increased (Figure 1). The riboflavin photostability significantly depends on the nature and physico-chemical characteristics of the solvent [52]. According to Huang et al., riboflavin absorbs light at different wavelengths triggering photodegradation, decomposing it in its major compounds lumichrome and lumiflavin, being this reaction enhanced at basic $\mathrm{pH}$ [53]. From these results, the $\mathrm{pH} 8.5$ was selected for further studies to promote crosslinking, since this value is still in the $\mathrm{pH}$ range commonly found in foods. The effect of the $\mathrm{pH}$ on crosslinking of gelatin suspensions was further investigated by rheology tests described in the following section.

\subsection{Characterization of Salmon Gelatin Hydrogels}

\subsubsection{Viscoelastic Behavior}

Figure 2 shows the viscoelastic behavior during the cooling stage of the different samples. The control samples (gelatin-riboflavin suspensions without light exposure) both at pH 5.0 and 8.5, showed a typical viscoelastic behavior with values of $G^{\prime \prime}>G^{\prime}$ at room temperature, with an increase on $G^{\prime}$ when reaching the gelling point. The gelling temperature was determined from the intersection point of both moduli corresponding to $6.7^{\circ} \mathrm{C}$ and $7.6^{\circ} \mathrm{C}$ at pH 5.0 and $\mathrm{pH} 8.5$, respectively. This difference in 
gelling temperature was probably due to differences in the $\mathrm{pH}$ altering the overall polymer structure configuration and chain to chain interactions, since the structure of the gelatin could be related to its interaction with the solvent, in this case water [54]. Indeed, since gelatin is produced by an acid extraction in this case, it presents an isoelectric point with values close to 9.0 as reported in our previous work [55].
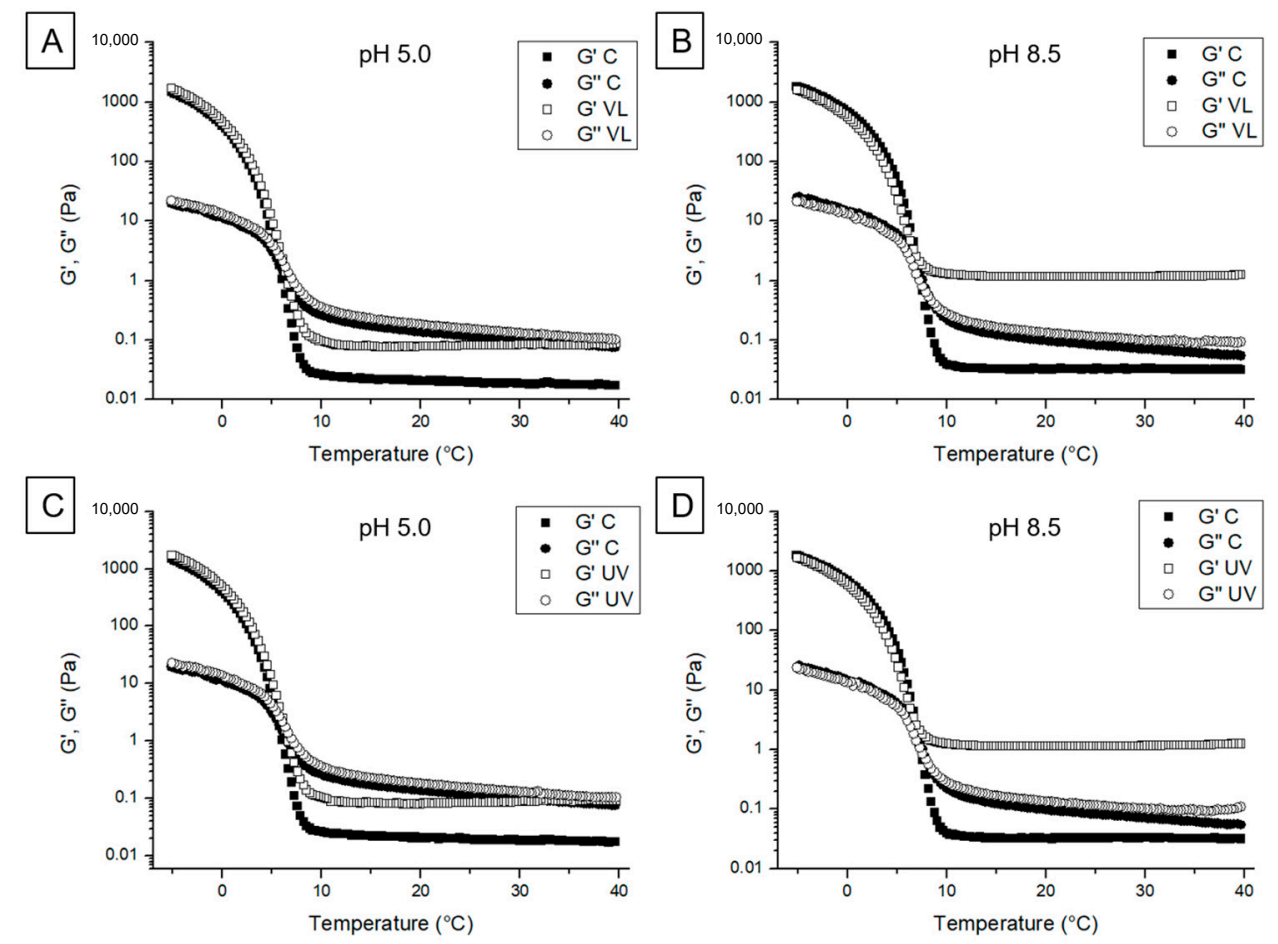

Figure 2. Storage modulus $\left(G^{\prime}\right)$ and the loss modulus $\left(G^{\prime \prime}\right)$ of gelatin-riboflavin suspensions on cooling. Visible light (VL): (A) and (B); ultraviolet light (UV): (C) and (D). Control (C): no light exposure.

After crosslinking at pH 5.0, $G^{\prime \prime}$ values were higher than $G^{\prime}$ for both UV and VL following the same trend as the controls but presenting higher storage modulus in the region above the gelling temperature (Figure 2A,C). However, when the $\mathrm{pH} 8.5$ suspensions were crosslinked, the elastic component was notoriously higher than the viscous component $\left(G^{\prime}>G^{\prime \prime}\right)$ showing a strong crosslinking effect both with UV and VL at room temperature (Figure 2B,D). Interestingly, in the crosslinked samples $G^{\prime}$ and $G^{\prime \prime}$ did not intersect at any point, but the exponential increase of both moduli occurred at a similar temperature to the control (near the gelling temperature). Likewise, as the cooling proceeded, the maximum values of $G^{\prime}$ and $G^{\prime \prime}$ did not change with respect to the control, suggesting that the triple helix formation was not affected by the light exposure.

A similar trend was observed in the heating stage curves, which showed a clear melting point in the $\mathrm{pH} 5.0$ control $\left(\mathrm{T}_{\mathrm{m}} \approx 12.6^{\circ} \mathrm{C}\right.$ ) (Figure $\left.3 \mathrm{~A}, \mathrm{C}\right)$ and a higher value $\left(15.0^{\circ} \mathrm{C}\right)$ in the case of $\mathrm{pH}$ 8.5 (Figure 3B,D). Again, after melting, the $\mathrm{pH} 5.0$ crosslinked samples showed a moderate increase of $G^{\prime}$ with both types of light exposure, while the $\mathrm{pH} 8.5$ crosslinked samples presented $G^{\prime}$ and $G^{\prime \prime}$ values notoriously higher. Therefore, crosslinking by UV or VL in the presence of riboflavin generated thermally resistant hydrogels that are resistant throughout the temperature range tested. This effect was even more significant at $\mathrm{pH} 8.5$. 

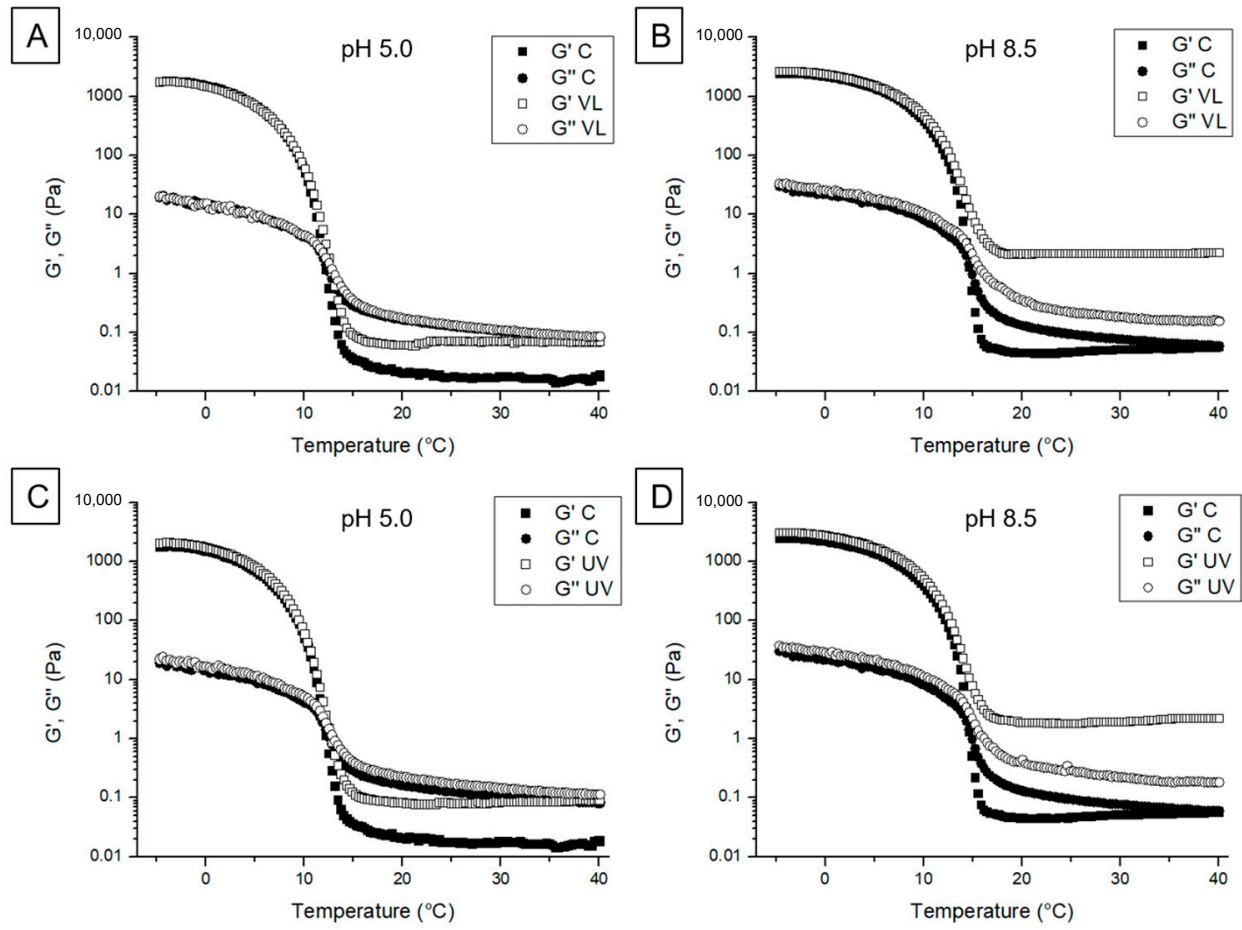

Figure 3. Storage modulus $\left(G^{\prime}\right)$ and the loss modulus $\left(G^{\prime \prime}\right)$ of crosslinked samples upon heating. Visible light (VL): (A) and (B); ultraviolet light (UV): F (C) and (D). Control (C): no light exposure.

Similarly, Chiou et al. [56] mentioned that gelatin samples with larger elastic modulus after gelation would be related to higher concentrations of helical structures within gelatin chains. In this work, the maximum values of $G^{\prime}$ and $G^{\prime \prime}$ (after gelling) did not change with respect to the control, reflecting that the triple helix formation was not affected by the light exposure suggesting that other elements of the gelatin structure may be involved in the crosslinking. Indeed, it has been described that when flavin moiety of riboflavin is exposed to UV/VL, the reactive species generated in the solution enhanced the probability of bond formation among riboflavin and amine molecules in gelatin, forming volume fractions on the backbone of the entire structure increasing the degree of shear thickening behavior by photo-crosslinking [57]. Additionally, it is well known that the concentration of helical structures are decreased during melting $[56,58]$. Therefore, as $G^{\prime}$ values of the crosslinked samples were higher than $G^{\prime}$ values of the control, the number of remaining polymerization structures in the riboflavin light exposed samples may have been higher than in the control, and this number should have been even larger at $\mathrm{pH}$ 8.5. Other cross-linking photoinitiators such as genipin and glutaraldehyde have been assessed to enhance the $G^{\prime}$ values of salmon gelatin [35]. The samples containing glutaraldehyde cross-linked much faster than those containing genipin. Salmon gelatin samples with $\mathrm{pH} 4.2$ also cross-linked faster than samples with $\mathrm{pH}$ 3.2. The authors mentioned that the effects of $\mathrm{pH}$ on gelatin cross-linking could be explained by the protonation of free amine groups in gelatin. At higher $\mathrm{pH}$, fewer amine groups became protonated generating greater concentration of free amine groups, which facilitated faster reaction rates [35].

The viscoelastic characterization of the crosslinked gelatins showed quantitatively the structural changes that occurred in the different formulations, with the aim to select the best conditions to achieve the stability and integrity of the coating when applied as a barrier material. Since these data demonstrated that UV light and VL exposure gave similar crosslinking results in terms of $G^{\prime}$ and $G^{\prime \prime}$ values, only hydrogels using SG-Rf suspensions adjusted to $\mathrm{pH} 8.5$ and exposed to VL (safer than UV) were selected for further characterization. 


\subsubsection{Apparent Viscosity}

The apparent viscosity of the hydrogels (SG-Rf pH 8.5, exposed to VL) upon cooling (Figure 4) showed higher values compared to the control (the same suspension with no VL exposure) resulting in $125.3 \mathrm{cP}$ versus $19.4 \mathrm{cP}$ at $25^{\circ} \mathrm{C}$, respectively. Interestingly, after the gelling occurred, the highest viscosity reached similar values in both cases (Figure 4). These results are in accordance with the viscoelastic behavior observed in the previous section, where $G^{\prime}$ of SG-Rf at $\mathrm{pH} 8.5$ exposed to VL was higher than the control at temperatures above $T_{\text {gel }}$, but it was similar to the control at temperatures below $T_{\text {gel }}$.

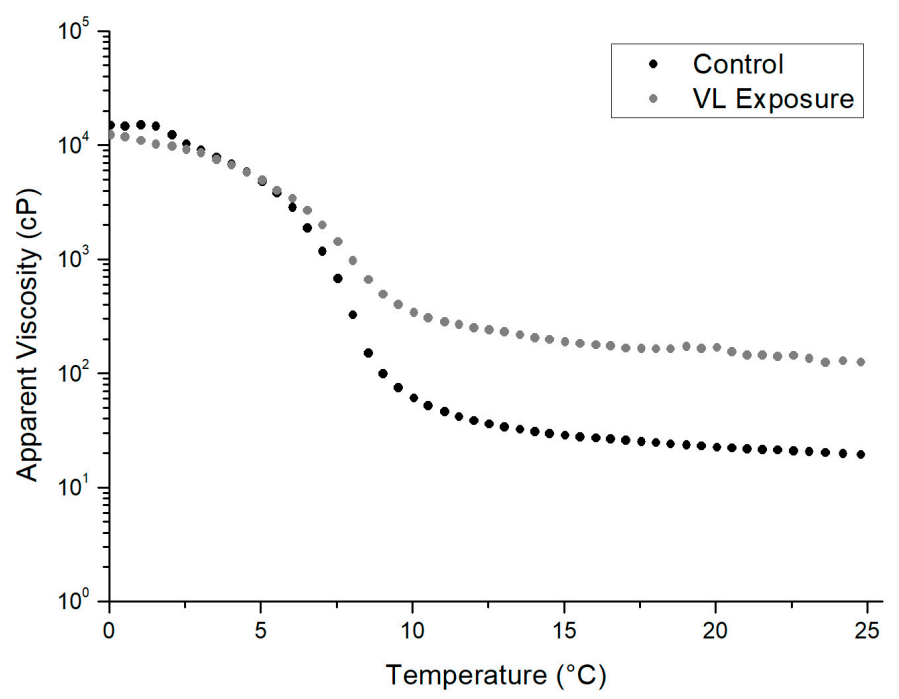

Figure 4. Apparent viscosity of the hydrogels exposed to visible light (VL) during the cooling ramp.

Demirbay et al. [57] also found that the viscosity of pure gelatin increased with the addition of riboflavin with UV exposure. They suggested that as the flavin group of riboflavin has a tendency to be involved in oxidation-reduction reactions when stimulated by UV light and the formation of reactive species in the solution enhanced the probability of bond formation among riboflavin and other organic molecules (such as gelatin and dextrin). In consequence, the formation of larger chains and groups of molecules on the backbone of the structure may have led to restricting the movement of entire molecule so viscosity of the sample increased after light exposure [57,59].

\subsubsection{Thermal Properties}

The gelling temperatures and the associated enthalpies were determined by DSC. The $T_{\text {gel }}$ of the samples was not significantly affected by the VL exposure (Table 1). In fact, in accordance to the rheological cooling curves, the increase of $G^{\prime}$ and $G^{\prime \prime}$ occurred at a similar temperature compared to the controls. Also, there were no significant differences among the gelling enthalpies of the treatments. This behavior suggests no changes on the triple helix formation by the photopolymerization, as suggested by rheology on previous sections.

Table 1. Thermal properties of salmon gelatin-riboflavin (SG-Rf) $\mathrm{pH} 8.5$ hydrogels.

\begin{tabular}{ccc}
\hline Treatment & $\boldsymbol{T}_{\text {gel }}\left({ }^{\circ} \mathbf{C}\right)$ & $\Delta H_{\text {gel }}\left(\mathbf{J g}^{-\mathbf{1}}\right)$ \\
\hline Control & $9.9 \pm 0.1^{\mathrm{a}}$ & $8.0 \pm 0.8^{\mathrm{a}}$ \\
VL exposure & $9.9 \pm 0.1^{\mathrm{a}}$ & $8.2 \pm 0.5^{\mathrm{a}}$ \\
\hline statistically significant $(p<0.05)$ between the treatments $(n=3)$.
\end{tabular}




\subsubsection{Light Transmittance}

The transmittance values ( $T \%$ ) of SG, SG-Rf pH 8.5 control suspensions and the VL crosslinked samples are shown in Figure 5. The control samples showed $0 \%$ transmittance up to a wavelength of $\sim 500 \mathrm{~nm}$, indicating that the addition of Rf affects $T \%$ in this interval. After the $500 \mathrm{~nm}$, the $T \%$ increased but it was the lowest in comparison with the SG and VL crosslinked samples. In fact, crosslinking considerably increased the transmittance with respect to the control, showing only a 10 $T \%$ lower than SG solution at wavelength values higher the $500 \mathrm{~nm}$.

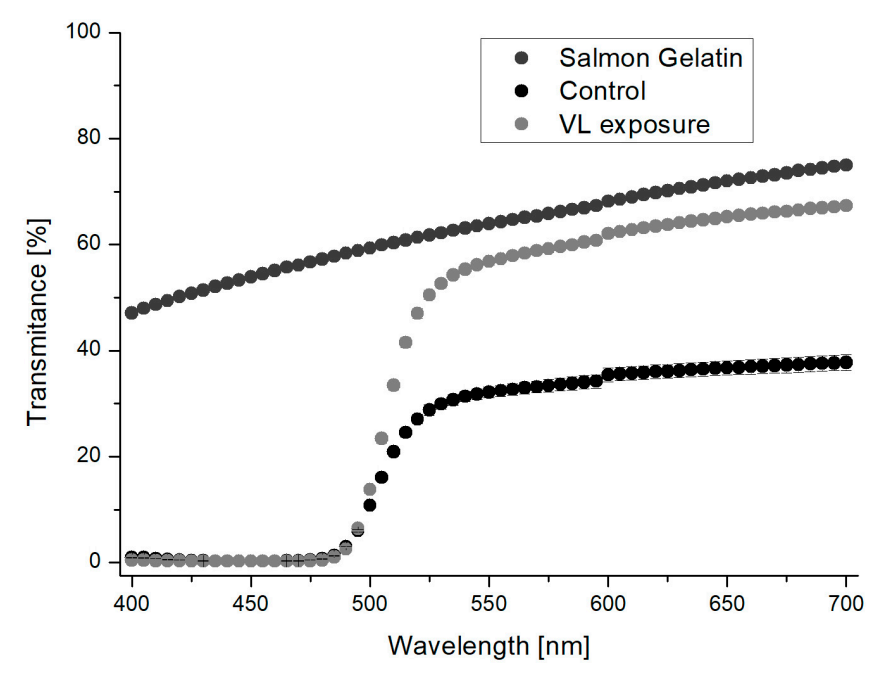

Figure 5. Transmittance (\%) visible spectrum (400-700 nm) of a salmon gelatin solution (SG), control samples (SG-Rf pH 8.5) and crosslinked samples (SG-Rf pH 8.5 with VL).

In addition, the yellow color intensity of the suspensions was notably lowered after exposure to visible light, which is directly related to the increase of transmittance. Huang et al. [53] reported that the decrease in the intensity of the color may be associated with the photodegradation of riboflavin in its compounds lumichrome and lumiflavin, which involve singlet oxygen, being enhanced at basic $\mathrm{pH}$ [53]. Demirbay et al. [59] also reported that the oxidation state of the flavin molecules can be followed up by considering the color of the resultant aqueous solutions. They observed that superoxidized flavins took a specific color of yellow-orange while fully-oxidized flavins appeared as light yellow.

\subsection{Evaluation of Salmon Gelatin-Riboflavin Hydrogels as a Sprayable Edible Coating}

Suspensions of SG-Rf pH 8.5 with VL exposure were assessed as a coating on fresh salmon fillets with the aim to preserve the microbial stability and some quality parameters of the fillets during cold storage $\left(2 \pm 0.5^{\circ} \mathrm{C}\right)$. Fresh salmon fillets with no coating were used as a control.

\subsubsection{Moisture loss of coated salmon fillets}

Moisture loss of coated and uncoated salmon fillets is shown in Figure 6, in terms of changes in sample weight. The coated fillets presented significant differences $(p<0.05)$ with respect to the control (2.5-2.7\%) during 7 and 14 days of storage, indicating that the crosslinked gelatin-based coating would prevent moisture loss from the fillets over time.

These results are in agreement with others authors that found that gelatin coatings significantly controlled the moisture loss from fish fillets during chilled storage [8,60]. Abdelhedi et al. [8], associating this feature with the presence of hydrophobic amino acids in the polymer, such as proline and leucine, thus the reducing effect on the weight loss in gelatin-coated samples. 

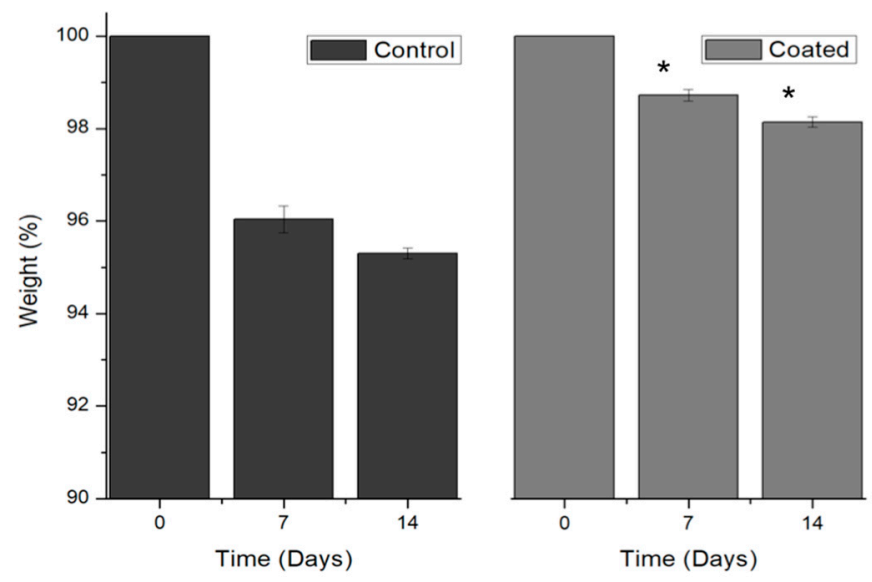

Figure 6. Weight $(\%)$ of coated salmon fillets and the untreated control stored at $2.0^{\circ} \pm 0.5^{\circ}$ for 14 days.

* Significant difference in coated fillets $(p<0.05)$ between the treatments $(n=3)$.

\subsection{2. $\mathrm{pH}$ Evolution of Coated Salmon Fillets}

The initial $\mathrm{pH}$ of the fillets was similar for both the control and the coated samples $(\mathrm{pH}$ 6.2) (Table 2). Therefore, the coating formed did not affect the $\mathrm{pH}$ of the surface. Overall, the $\mathrm{pH}$ did not vary significantly $(p>0.05)$ between the coated and control fillets during the first 6 days of storage. However, at the end of storage (13 days) the $\mathrm{pH}$ of the control significantly increased while the coated sample was maintained.

Table 2. PH of coated salmon fillets and the untreated control, stored at $2.0 \pm 0.5^{\circ} \mathrm{C}(n=4)$.

\begin{tabular}{cccccc}
\hline \multirow{2}{*}{ Sample } & $\mathbf{5}$ & Time (days) \\
\cline { 2 - 6 } & $\mathbf{0}$ & $\mathbf{4}$ & $\mathbf{6}$ & $\mathbf{8}$ & $\mathbf{1 3}$ \\
\hline Control & $6.21 \pm 0.05^{\mathrm{a}}$ & $6.10 \pm 0.03^{\mathrm{a}}$ & $6.12 \pm 0.03^{\mathrm{a}}$ & $6.02 \pm 0.03^{\mathrm{b}}$ & $6.46 \pm 0.08^{\mathrm{b}}$ \\
Coated & $6.20 \pm 0.02^{\mathrm{a}}$ & $6.10 \pm 0.08^{\mathrm{a}}$ & $6.13 \pm 0.03^{\mathrm{a}}$ & $6.11 \pm 0.03^{\mathrm{a}}$ & $6.14 \pm 0.02^{\mathrm{a}}$ \\
\hline a,b Different letters indicate significant differences $(p<0.05)$ between the control and coated samples.
\end{tabular}

a,b Different letters indicate significant differences $(p<0.05)$ between the control and coated samples.

In accordance with our results, Wang et al. [9] reported an increase of $\mathrm{pH}$ values of the control salmon fillets after 9 days storage at $4.0 \pm 1.0^{\circ} \mathrm{C}$, whereas the coated fillets with a formulation based on collagen and lysozyme remained unaltered until day 12 . This increase of $\mathrm{pH}$ was explained by the formation of basic compounds such as $\mathrm{NH}_{3}$ groups and trimethylamine by the hydrolytic effect of the increasing amounts of spoilage bacteria $[8,61]$.

\subsubsection{Color Evolution of Coated Salmon Fillets}

Color is a key parameter in food quality that influences the consumer's acceptability. The pink-red color of salmon flesh is due mainly to the presence of astaxanthin, the major carotenoid naturally found in wild salmon and crustaceans (shrimp, lobsters). Yagiz et al. [62] reported a correlation in the reduction of astaxanthin concentration in the muscle and the $\mathrm{a}^{*}$ value, decreasing with increasing electron-beam irradiation doses. Also, no changes in $\mathrm{a}^{*}$ corroborated the color maintenance in coated samples.

Figure 7 shows the color parameters clarity $\left(\mathrm{L}^{*}, \mathrm{a}^{*}\right.$, and $\left.\mathrm{b}^{*}\right)$ of the salmon fillets measured at the beginning and at end of the storage time. 

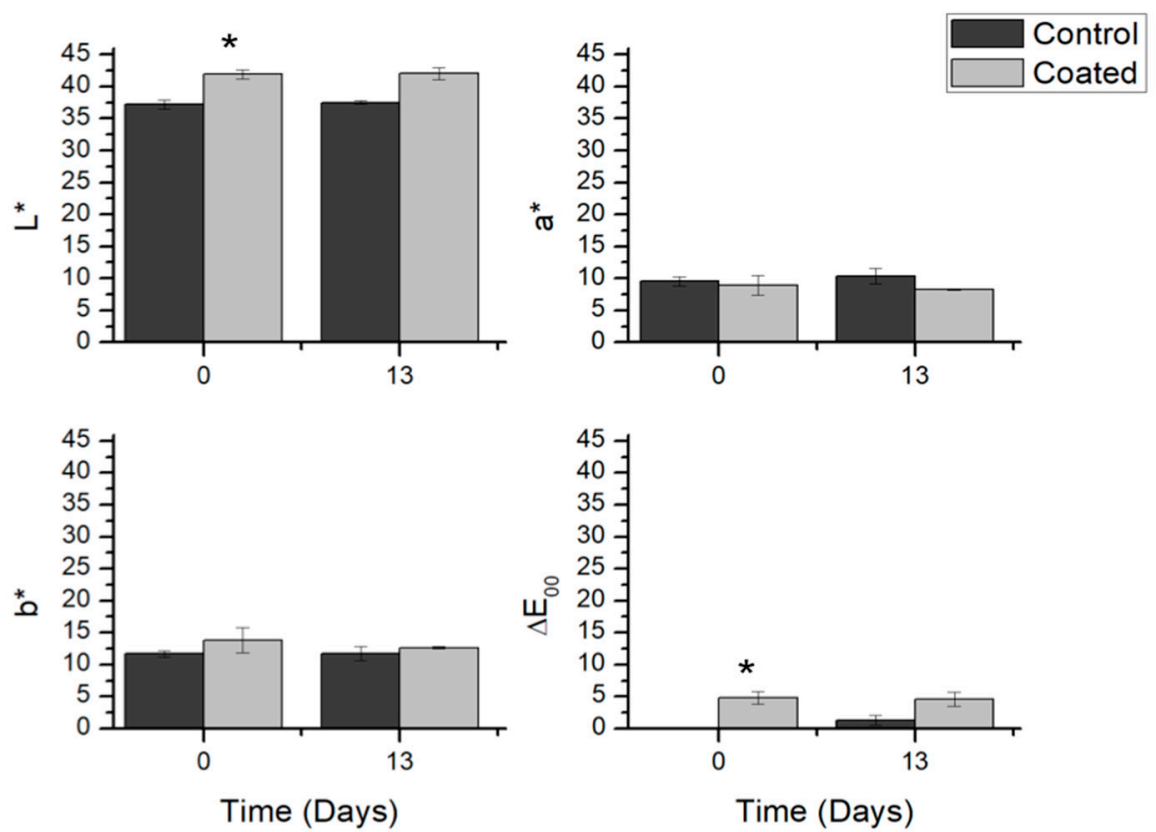

Figure 7. Color parameters $\left(\mathrm{L}^{*}, \mathrm{a}^{*}, \mathrm{~b}^{*}\right.$, and $\left.\Delta E_{00}\right)$ of coated salmon fillets and the untreated control, stored at $2.0 \pm 0.5^{\circ} \mathrm{C} .{ }^{*}$ Significant difference $(p<0.05)$ between the control and coated samples $(n=4)$.

The coated salmon showed a $L^{*}$ value greater than the control at the beginning of storage. However, the red $\left(a^{*}\right)$ and yellow $\left(b^{*}\right)$ components showed no significant differences $(p>0.05)$ with respect to the control, indicating that discoloration did not occur over the storage time. The differences were maintained throughout the storage without a significant increase. However, the total color-difference $\left(\Delta E_{00}\right)$ values showed evident differences between the control and the coated samples at day 0. Interestingly, these differences in the coated samples were maintained over time with no changes. Conversely, the uncoated sample increased the total color-difference with respect to the initial values, showing marked differences on day 13. Therefore, the coating prevented loss of coloration at the fillet surface, possible slowing it down by protecting it from the environment. Also, it has to be noticed that although riboflavin is a colored additive, there were little differences between the coated sample and the control at the beginning of storage, since the crosslinking increased the transmittance of the crosslinked hydrogel as indicated in Section 3.2.4.

A study reported that gelatin and gelatin incorporated with $2 \%$ orange leaf essential oil used as a coating on deep water pink shrimps prevented the melanosis that occurs by oxidation preserving the quality for 14 days in cold storage [61]. The authors mentioned that the clarity, redness, and yellowness were significantly higher in the gelatin coated samples than in the untreated control, remarking the barrier effect of the gelatin coating. In addition, other color changes may occur due to myoglobin oxidation. Gelatin coating offers an excellent barrier to avoid oxygen penetration preventing the oxidation, as demonstrated by Feng et al. [60] using gelatin as edible coating to protect golden pomfret fillet during cold storage. Further work will consider evaluating the effect of oxidation processes on color during storage.

\subsubsection{Microbiological Stability of Coated Salmon Fillets}

The most commonly reported spoilage bacteria for aerobically stored chilled salmon have been species within the genera Pseudomonas and Shewanella, being the processing environment the source of contamination [63]. In addition, Photobacterium phosphoreum have been associated to fish packed under modified atmosphere because of the $\mathrm{CO}_{2}$-resistance, which most likely originated from the live fish and seawater [63]. In this study, the total mesophilic aerobic count of the fillets during the cold storage was assed and presented in Figure 8. The coated salmon presented significant differences with 
respect to the untreated control, which reached $10^{7} \mathrm{CFU} / \mathrm{g}$ (maximum level allowed by the European legislation) (International Commission on Microbiological Specifications for Foods, ICMSF) [64] at day 9 (Figure 8A). The coated salmon was most effective in reducing this growth, extending by $37 \%$ (from 9 to 12.4 days) the time to reach the maximum level allowed by the regulations.
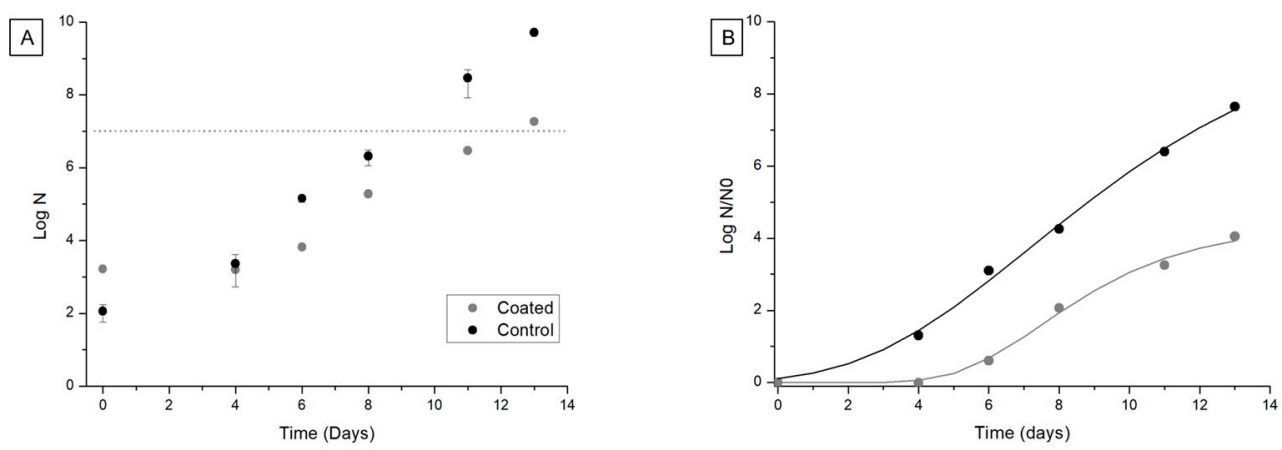

Figure 8. Total mesophilic aerobic count of salmon fillets treated with gelatin coating and stored at $2 \pm 0.5^{\circ} \mathrm{C}$ for 13 days $(n=4)$. (A) Experimental data plot; (B) Gompertz model (lines) and normalized experimental data (points).

The microbial growth curves presented a nonlinear behavior, so the data were modeled using the reparametrized modified Gompertz equation (Equation (2)) with the aim to quantify the growth response by determination of the kinetic parameters $(\lambda, \mu \mathrm{m}$ and A). Figure 8 presents the experimental and modeled data expressed as log of the normalized data in order to simplify the analysis.

The model accounted for more than $99 \%$ of the correlation in the growth counts since the adjusted determination coefficient ( $\mathrm{R}^{2}$ adj) ranged between $99.1 \%$ and $99.5 \%$ (Table 3). Also, the low RMSE values obtained, showed a good fit of the data. The quantification of the microbial response showed that the delay on microbial growth was in part due to the lag phase extension (from 2.4 days for the control to 5.1 days for the coated salmon and also due to the lower growth rate of the treated samples (1.5 $\mathrm{d}^{-1}$ compared to $1.8 \mathrm{~d}^{-1}$ of the control).

Table 3. Growth kinetic parameters of total mesophilic aerobic microorganisms calculated from the application of the modified Gompertz model.

\begin{tabular}{cccccccc}
\hline Treatment & $\boldsymbol{\lambda} \mathbf{( d )}$ & $\boldsymbol{\mu} \mathbf{m}\left(\mathbf{d}^{-\mathbf{1}}\right)$ & $\mathbf{A}$ & Growth Cycles & $\mathbf{R}^{\mathbf{2}}$ & $\mathbf{R}^{\mathbf{2}} \mathbf{a j}$ & $\mathbf{R M S E}$ \\
\hline Control & 2.4 & 1.8 & 23.3 & 10.1 & 99.7 & 99.5 & 0.21 \\
Coating & 5.1 & 1.5 & 10.0 & 4.3 & 99.5 & 99.1 & 0.16 \\
\hline
\end{tabular}

Møretrø et al. [63] reported that industrially processed salmon fillets had initial bacterial levels in the range 1.4-2.9 $\log$ CFU/g 1-2 days after production and reached 3.3-5.9 $\log$ CFU/g after 10 days in ice storage $\left(<1^{\circ} \mathrm{C}\right)$. On the other hand, an ice-glazing based on chitosan-gelatin incorporated with lime peel essential oil extended more than $50 \%$ the time to reach counts of $10^{6} \mathrm{CFU} / \mathrm{g}$ on rainbow trout fillets under superchilled storage $\left(-1.4{ }^{\circ} \mathrm{C}\right.$ for 30 days) compared to the untreated control [65]. The lower storage temperatures used in these works $\left(<1^{\circ} \mathrm{C}\right.$ and $-1.4^{\circ} \mathrm{C}$, respectively) may account for the differences on the observed final counts of this manuscript $\left(2.0 \pm 0.5^{\circ} \mathrm{C}\right)$. It is known that low temperatures $\left(-1\right.$ to $-2{ }^{\circ} \mathrm{C}$ ) are key factors slowing down the growth of microorganisms by deceleration of enzymatic reactions or deactivation of microbial enzymes [66].

Other works also demonstrated that gelatin coating significantly reduced the growth of spoilage microorganisms as compared to the control $([8,65,67]$. The effect of edible gelatin coating may be due to its barrier role against oxygen diffusion and thus reduction of the proliferation of the numerous aerobic bacteria (i.e., Pseudomonas) present on fish by forming a protein bio-film around the fillets [8]. However, 
a possible effect of the gelatin itself cannot be discarded completely, since it has been described that hydrolyzed fish gelatin presents antibacterial properties [68,69]

\section{Conclusions}

The photopolymerization of salmon gelatin using riboflavin as photoinitiator allowed its stabilization to use it as a coating on salmon fillets. The rheological parameters demonstrated that the crosslinking reaction of salmon gelatin with riboflavin could be developed not only by UV but also with VL, with the advantage of using safer process operation. The $\mathrm{pH}$ adjustment to 8.5 was necessary to generate a stronger crosslinking effect. The gelling temperature was not affected by the presence of riboflavin which was tested by both DSC and rheological methods. Therefore, the riboflavin promotes molecular changes among gelatin chains (not associated to the triple helix formation) that would account for the increase in viscosity and $G^{\prime}$. Also, light transmittance was similar to pure salmon gelatin suspensions (in wavelengths over $500 \mathrm{~nm}$ ) suggesting that a gelatin-riboflavin-based coating under the tested conditions should not alter the visual appearance of the coated fillets. The formulated coating was effective to preserve the microbiological stability and quality parameters during refrigerated storage. In fact, microbial spoilage was significantly delayed (37\%), with a reduced weight loss and no considerable changes in $\mathrm{pH}$ and color. Therefore, photopolymerization of low viscosity gelatins such as sprayable salmon gelatin in combination with riboflavin as photoinitiator and exposed to visible light allowed the formation of stable hydrogel as a coating. The cross-linking reaction was carried out in real time and with elements of proven safety which would allow scaling up at the industrial level. Thus, this formulation allows to use a biomaterial obtained from a by-product opening up interesting perspectives of extending shelf-life of salmon or similar products using a novel and safe technology.

Author Contributions: Conceptualization, J.E.; Project Administration, P.D.-C., J.E., Supervision, J.E.; Methodology, C.C., C.P., V.C., M.P.; Formal Analysis, C.C., C.P., V.C.; Investigation, C.C., C.P., V.C., M.P., P.D.-C; Writing-Original Draft Preparation, C.C., C.P., V.C.; Writing-Review and Editing, P.D.-C., J.E.; Funding Acquisition, P.D.-C., J.E.

Funding: This research was funded by “Fondo Nacional de Desarrollo Científico y Tecnológico" (Fondecyt), grant number 1171557", "Fondo de Fomento al Desarrollo Científico y Tecnológico" (FONDEF), grant number ID16I-10484 and by the governmental agency "Corporación de Fomento de Producción" (CORFO) grant number 16-CONTEC-67402.

Conflicts of Interest: The authors declare no conflict of interest.

\section{References}

1. Karim, A.A.; Bhat, R. Fish Gelatin: Properties, Challenges, and Prospects as an Alternative to Mammalian Gelatins. Food Hydrocoll. 2009, 23, 563-576. [CrossRef]

2. Djagny, K.B.; Wang, Z.; Xu, S.; Djagny, K.B.; Wang, Z.; Xu, S. Gelatin: A Valuable Protein for Food and Pharmaceutical Industries. Crit. Rev. Food Sci. Nutr. 2017, 41, 481-492. [CrossRef] [PubMed]

3. Hosseini, S.F.; Gómez-guillén, M.C. A State-of-the-Art Review on the Elaboration of Fish Gelatin as Bioactive Packaging: Special Emphasis on Nanotechnology-Based Approaches. Trends Food Sci. Technol. 2018, 79, 125-135. [CrossRef]

4. Hanani, Z.A.N.; Roos, Y.H.; Kerry, J.P. Use and Application of Gelatin as Potential Biodegradable Packaging Materials for Food Products. Int. J. Biol. Macromol. 2014, 71, 94-102. [CrossRef] [PubMed]

5. Gómez-Guillén, M.; Pérez-Mateos, M.; Gómez-Estaca, J.; López-Caballero, E.; Giménez, B.; Montero, P. Fish Gelatin: A Renewable Material for Developing Active Biodegradable Films. Trends Food Sci. Technol. 2009, 20, 3-16. [CrossRef]

6. Wang, L.; Liu, L.; Holmes, J.; Kerry, J.F.; Kerry, J.P. Original Article Assessment of Film-Forming Potential and Properties of Protein and Polysaccharide-Based Biopolymer Films. Food Sci. Technol. 2007, 42, 1128-1138. [CrossRef]

7. Antoniewski, M.N.; Barringer, C.L.; Knipe, C.L.; Zerby, H.N. Effect of a Gelatin Coating on the Shelf Life of Fresh Meat. Food Eng. Phys. Prop. 2007, 72, E382-E387. [CrossRef] 
8. Abdelhedi, O.; Jridi, M.; Nasri, R.; Mora, L.; Toldrá, F.; Nasri, M. Rheological and Structural Properties of Hemiramphus Far Skin Gelatin: Potential Use as an Active Fish Coating Agent. Food Hydrocoll. 2019, 87, 331-341. [CrossRef]

9. Wang, Z.; Hu, S.; Gao, Y.; Ye, C.; Wang, H. Effect of Collagen-Lysozyme Coating on Fresh-Salmon Fillets Preservation. LWT-Food Sci. Technol. 2017, 75, 59-64. [CrossRef]

10. Zhou, Q.; Li, P.; Fang, S.; Liu, W.; Mei, J.; Xie, J. Preservative Effects of Gelatin Active Coating Enriched with Eugenol Emulsion on Chinese Seabass (Lateolabrax Maculatus) during Superchilling $\left(-0.9^{\circ} \mathrm{C}\right)$ Storage. Coatings 2019, 9, 498. [CrossRef]

11. Andreuccetti, C.; Carvalho, R.A.; Grosso, C.R.F. Gelatin-Based Films Containing Hydrophobic Plasticizers and Saponin from Yucca Schidigera as the Surfactant. Food Res. Int. 2010, 43, 1710-1718. [CrossRef]

12. Díaz, P.; López, D.; Matiacevich, S.; Osorio, F.; Enrione, J. State Diagram of Salmon (Salmo Salar) Gelatin Films. J. Sci. Food Agric. 2011, 91, 2558-2565. [CrossRef] [PubMed]

13. Li, J.; Miao, J.; Wu, J.; Chen, S.; Zhang, Q. Food Hydrocolloids Preparation and Characterization of Active Gelatin-Based Fi Lms Incorporated with Natural Antioxidants. Food Hydrocoll. 2014, 37, 166-173. [CrossRef]

14. Ma, W.; Tang, C.; Yin, S.; Yang, X.; Wang, Q.; Liu, F.; Wei, Z. Characterization of Gelatin-Based Edible Films Incorporated with Olive Oil. FRIN-Food Res. Int. 2012, 49, 572-579. [CrossRef]

15. Ramos, M.; Valdes, A.; Beltran, A.; Garrigos, M.C. Gelatin-Based Films and Coatings for Food Packaging Applications. Coatings 2016, 6, 41. [CrossRef]

16. Wihodo, M.; Moraru, C.I. Physical and Chemical Methods Used to Enhance the Structure and Mechanical Properties of Protein Films: A Review. J. Food Eng. 2013, 114, 292-302. [CrossRef]

17. Fakhouri, F.M.; Martelli, S.M.; Caon, T.; Velasco, J.I.; Mei, L.H.I. Edible Films and Coatings Based on Starch/Gelatin: Film Properties and Effect of Coatings on Quality of Refrigerated Red Crimson Grapes. Postharvest Biol. Technol. 2015, 109, 57-64. [CrossRef]

18. Nata, I.F.; Irawan, C.; Ramadhan, L.; Ramadhani, M.R. Influence of Soy Protein Isolate on Gelatin-Based Edible Film Properties. MATEC Web Conf. 2018, 156, 01014. [CrossRef]

19. Rivero, S.; García, M.A.; Pinotti, A. Composite and Bi-Layer Films Based on Gelatin and Chitosan. J. Food Eng. 2009, 90, 531-539. [CrossRef]

20. Quero, F.; Coveney, A.; Lewandowska, A.E.; Richardson, R.M.; Lee, K.; Eichhorn, S.J.; Alam, M.A.; Enrione, J. Stress Transfer Quantification in Gelatin-Matrix Natural Composites with Tunable Optical Properties. Biomacromolecules 2015, 16, 1784-1793. [CrossRef]

21. Carvalho, R.A.; De Grosso, C.R.F. Characterization of Gelatin Based Films Modified with Transglutaminase, Glyoxal and Formaldehyde. Food Hydrocoll. 2004, 18, 717-726. [CrossRef]

22. Mu, C.; Guo, J.; Li, X.; Lin, W.; Li, D. Food Hydrocolloids Preparation and Properties of Dialdehyde Carboxymethyl Cellulose Crosslinked Gelatin Edible Fi Lms. Food Hydrocoll. 2012, 27, 22-29. [CrossRef]

23. Arnesen, J.A.; Gildberg, A. Extraction and Characterisation of Gelatine from Atlantic Salmon (Salmo Salar) Skin. Bioresour. Technol. 2007, 98, 53-57. [CrossRef]

24. Silvipriya, K.S.; Kumar, K.K.; Bhat, A.R.; Kumar, B.D.; John, A.; Lakshmanan, P. Collagen: Animal Sources and Biomedical Application. J. Appl. Pharm. Sci. Vol. 2015, 5, 123-127. [CrossRef]

25. Haug, I.J.; Draget, K.I.; Smidsrød, O. Physical and Rheological Properties of Fish Gelatin Compared to Mammalian Gelatin. Food Hydrocoll. 2004, 18, 203-213. [CrossRef]

26. Joly-Duhamel, C.; Hellio, D.; Djabourov, M. All Gelatin Networks: 1. Biodiversity and Physical Chemistry. Langmuir 2002, 18, 7208-7217. [CrossRef]

27. Ninan, G.; Joseph, J. A Comparative Study on the Physical, Chemical and Functional Properties of Carp Skin and Mammalian Gelatins. J. Food Sci. Technol. 2014, 51, 2085-2091. [CrossRef]

28. Nurul, A.G.; Sarbon, N.M. Effects of PH on Functional, Rheological and Structural Properties of Eel (Monopterus Sp.) Skin Gelatin Compared to Bovine Gelatin. Int. Food Res. J. 2015, 22, 572-583.

29. Díaz-Calderón, P.; Flores, E.; González-Muñoz, A.; Pepczynska, M.; Quero, F.; Enrione, J. Influence of Extraction Variables on the Structure and Physical Properties of Salmon Gelatin. Food Hydrocoll. 2017, 71, 118-128. [CrossRef]

30. Cho, S.M.; Gu, Y.S.; Kim, S.B. Extracting Optimization and Physical Properties of Yellowfin Tuna (Thunnus Albacares) Skin Gelatin Compared to Mammalian Gelatins. Food Hydrocoll. 2005, 19, 221-229. [CrossRef]

31. Elharfaoui, N.; Djabourov, M.; Babel, W. Molecular Weight Influence on Gelatin Gels: Structure, Enthalpy and Rheology. Macromol. Symp. 2007, 256, 149-157. [CrossRef] 
32. Eysturskarð, J.; Haug, I.J. Mechanical Properties of Mammalian and Fish Gelatins as a Function of the Contents of $\alpha$-Chain, $\beta$-Chain, and Low and High Molecular Weight Fractions. Food Biophys. 2010, 5, 9-16. [CrossRef]

33. Gómez-Estaca, J.; Montero, P.; Fernández-Martín, F.; Gómez-Guillén, M. Physico-Chemical and Film-Forming Properties of Bovine-Hide and Tuna-Skin Gelatin: A Comparative Study. J. Food Eng. 2009, 90, 480-486. [CrossRef]

34. Bigi, A.; Cojazzi, G.; Panzavolta, S.; Rubini, K.; Roveri, N. Mechanical and Thermal Properties of Gelatin Films at Different Degrees of Glutaraldehyde Crosslinking. Biomaterials 2001, 22, 763-768. [CrossRef]

35. Chiou, B.S.; Avena-Bustillos, R.J.; Shey, J.; Yee, E.; Bechtel, P.J.; Imam, S.H.; Glenn, G.M.; Orts, W.J. Rheological and Mechanical Properties of Cross-Linked Fish Gelatins. Polymer (Guildford) 2006, 47, 6379-6386. [CrossRef]

36. Ofner, C.M.; Zhang, Y.E.; Jobeck, V.C.; Bowman, B.J. Crosslinking Studies in Gelatin Capsules Treated with Formaldehyde and in Capsules Exposed to Elevated Temperature and Humidity. J. Pharm. Sci. 2001, 90, 79-88. [CrossRef]

37. Kuijpers, A.J.; Engbers, G.H.M.; Krijgsveld, J.; Zaat, S.A.J.; Feijen, J. Cross-Linking and Characterisation of Gelatin Matrices for Biomedical Applications. J. Biomater. Sci. Polym. Ed. 2000, 11, 225-243. [CrossRef] [PubMed]

38. Klotz, B.J.; Gawlitta, D.; Rosenberg, A.J.W.P.; Malda, J.; Melchels, F.P.W. Gelatin-Methacryloyl Hydrogels: Towards Biofabrication-Based Tissue Repair. Trends Biotechnol. 2016, 34, 394-407. [CrossRef]

39. Yue, K.; Trujillo-de Santiago, G.; Alvarez, M.M.; Tamayol, A.; Annabi, N.; Khademhosseini, A. Biomaterials Synthesis, Properties, and Biomedical Applications of Gelatin Methacryloyl (GelMA) Hydrogels. Biomaterials 2015, 73, 254-271. [CrossRef]

40. Yang, G.; Xiao, Z.; Ren, X.; Long, H.; Qian, H.; Ma, K.; Guo, Y. Enzymatically Crosslinked Gelatin Hydrogel Promotes the Proliferation of Adipose Tissue-Derived Stromal Cells. PeerJ 2016, 4, e2497. [CrossRef]

41. Heo, J.; Koh, R.H.; Shim, W.; Kim, H.D.; Yim, H.; Hwang, N.S. Riboflavin-Induced Photo-Crosslinking of Collagen Hydrogel and Its Application in Meniscus Tissue Engineering. Drug Deliv. Transl. Res. 2015, 6, 148-158. [CrossRef] [PubMed]

42. Jang, J.; Kim, T.G.; Kim, B.S.; Kim, S.-W.; Kwon, S.-M.; Cho, D.-W. Tailoring Mechanical Properties of Decellularized Extracellular Matrix Bioink by Vitamin B2-Induced Photo-Crosslinking. Acta Biomater. 2016, 33, 88-95. [CrossRef] [PubMed]

43. Tirella, A.; Liberto, T.; Ahluwalia, A. Riboflavin and Collagen: New Crosslinking Methods to Tailor the Stiffness of Hydrogels. Mater. Lett. 2012, 74, 58-61. [CrossRef]

44. Wang, K.; Wang, W.; Wu, X.; Xiao, J.; Liu, Y. Effect of Photochemical UV/ Riboflavin-Mediated Cross-Links on Different Properties of Fish Gelatin Films. J. Food Process Eng. 2017, 40, e12536. [CrossRef]

45. Zhang, Y.; Conrad, A.H.; Conrad, G.W. Effects of Ultraviolet-A and Riboflavin on the Interaction of Collagen and Proteoglycans during Corneal Cross-Linking. J. Biol. Chem. 2011, 286, 13011-13022. [CrossRef]

46. Ibusuki, S.; Halbesma, G.J.; Randolph, M.A.; Redmond, R.W.; Kochevar, I.E.; Gill, T.J. Photochemically Cross-Linked Collagen Gels as Three-Dimensional Scaffolds for Tissue Engineering. Tissue Eng. 2007, 13, 1995-2001. [CrossRef]

47. Sharma, G.; Wu, W.; Dalal, E.N. The CIEDE2000 Color-Difference Formula: Implementation Notes, Supplementary Test Data, and Mathematical Observations. Color Res. Appl. 2005, 30, 21-30. [CrossRef]

48. International Organization for Standardization. International Standard ISO/IEC Information Technology-Security Techniques-Information Security Management Systems-Requirements; International Organization for Standardization: Geneva, Switzerland, 2013.

49. Zwietering, M.H.; Jongenburger, I.; Rombouts, F.M.; van't Riet, K. Modeling of the Bacterial Growth Curve. Appl. Environ. Microbiol. 1990, 56, 1875-1881.

50. Pina-Pérez, M.C.; González, A.; Moreno, Y.; Ferrús, M.A. Helicobacter Pylori Growth Pattern in Reference Media and Extracts from Selected Minimally Processed Vegetables. Food Control 2018, 86, 389-396. [CrossRef]

51. Zanetti-Polzi, L.; Aschi, M.; Daidone, I.; Amadei, A. Theoretical Modeling of the Absorption Spectrum of Aqueous Riboflavin. Chem. Phys. Lett. 2017, 669, 119-124. [CrossRef]

52. Kasimova, G.K.; Astanov, S.K.; Kurtaliev, E.N.; Nizomov, N.N. Structure of Self-Assembled Riboflavin Molecules in Solutions. J. Mol. Struct. 2019, 1185, 107-111. [CrossRef]

53. Huang, R.; Hyun, J.K.; Min, D.B. Photosensitizing Effect of Riboflavin, Lumiflavin, and Lumichrome on the Generation of Volatiles in Soy Milk. J. Agric. Food Chem. 2006, 54, 2359-2364. [CrossRef] [PubMed] 
54. Lin, W.; Yan, L.; Mu, C.; Li, W.; Zhang, M.; Zhu, Q. Effect of PH on Gelatin Self-Association Investigated by Laser Light Scattering and Atomic Force Microscopy. Polym. Int. 2002, 51, 233-238. [CrossRef]

55. Zaupa, A.; Byres, N.; Dal Zovo, C.; Acevedo, C.A.; Angelopoulos, I.; Terraza, C.; Nestle, N.; Abarzúa-Illanes, P.N.; Quero, F.; Díaz-Calderón, P.; et al. Cold-Adaptation of a Methacrylamide Gelatin towards the Expansion of the Biomaterial Toolbox for Specialized Functionalities in Tissue Engineering. Mater. Sci. Eng. C 2019, 102, 373-390. [CrossRef] [PubMed]

56. Chiou, B.-S.; Avena-Bustillos, R.J.; Bechtel, P.J.; Jafri, H.; Narayan, R.; Imam, S.H.; Glenn, G.M.; Orts, W.J. Cold Water Fish Gelatin Films: Effects of Cross-Linking on Thermal, Mechanical, Barrier, and Biodegradation Properties. Eur. Polym. J. 2008, 44, 3748-3753. [CrossRef]

57. Demirbay, B.; Akaoğlu, C.; Ulusaraç, İ.; Gülay Acar, F. Thermal and UV Radiation Effects on Dynamic Viscosity of Gelatin-Based Riboflavin Solutions. J. Mol. Liq. 2017, 225, 147-150. [CrossRef]

58. Goudoulas, T.B.; Germann, N. Phase Transition Kinetics and Rheology of Gelatin-Alginate Mixtures. Food Hydrocoll. 2017, 66, 49-60. [CrossRef]

59. Demirbay, B.; Ata Ayhan, A.; Cereyan, N.; Akaoğlu, C.; Ulusaraç, İ.; Koyuncu, N.; Gülay Acar, F. Rheological Properties of Dextrin-Riboflavin Solutions under Thermal and UV Radiation Effects. J. Mol. Liq. 2017, 240, 597-603. [CrossRef]

60. Feng, X.; Bansal, N.; Yang, H. Fish Gelatin Combined with Chitosan Coating Inhibits Myofibril Degradation of Golden Pomfret (Trachinotus Blochii) Fillet during Cold Storage. Food Chem. 2016, 200, 283-292. [CrossRef]

61. Alparslan, Y.; Yapıcı, H.H.; Metin, C.; Baygar, T.; Günlü, A.; Baygar, T. Quality Assessment of Shrimps Preserved with Orange Leaf Essential Oil Incorporated Gelatin. LWT-Food Sci. Technol. 2016, 72, 457-466. [CrossRef]

62. Yagiz, Y.; Kristinsson, H.G.; Balaban, M.O.; Welt, B.A.; Raghavan, S.; Marshall, M.R. Correlation between Astaxanthin Amount and A* Value in Fresh Atlantic Salmon (Salmo Salar) Muscle during Different Irradiation Doses. Food Chem. 2010, 120, 121-127. [CrossRef]

63. Møretrø, T.; Moen, B.; Heir, E.; Hansen, A.Å.; Langsrud, S. Contamination of Salmon Fillets and Processing Plants with Spoilage Bacteria. Int. J. Food Microbiol. 2016, 237, 98-108. [CrossRef] [PubMed]

64. ICMSF. Microorganisms in Foods 2: Sampling for Microbiological Analysis: Principles and Specific Applications; Blackwell Scientific Publications: Oxford, UK, 1986.

65. Sarmast, E.; Fallah, A.A.; Habibian Dehkordi, S.; Rafieian-Kopaei, M. Impact of Glazing Based on Chitosan-Gelatin Incorporated with Persian Lime (Citrus Latifolia) Peel Essential Oil on Quality of Rainbow Trout Fillets Stored at Superchilled Condition. Int. J. Biol. Macromol. 2019, 136, 316-323. [CrossRef] [PubMed]

66. Banerjee, R.; Maheswarappa, N.B. Superchilling of Muscle Foods: Potential Alternative for Chilling and Freezing. Crit. Rev. Food Sci. Nutr. 2019, 59, 1256-1263. [CrossRef] [PubMed]

67. Hosseini, S.F.; Rezaei, M.; Zandi, M.; Ghavi, F.F. Effect of Fish Gelatin Coating Enriched with Oregano Essential Oil on the Quality of Refrigerated Rainbow Trout Fillet. J. Aquat. Food Prod. Technol. 2016, 25, 835-842. [CrossRef]

68. Gómez-Guillén, M.C.; López-Caballero, M.E.; Alemán, A.; Lopez de Lacey, A.; Giménez, B.; Montero, P. Antioxidant and Antimicrobial Peptide Fractions from Squid and Tuna Skin Gelatin. In Sea By-Products as Real Material: New Ways of Application; Bihan, E.L., Ed.; Transworld Research Network: Trivandrum, India, 2010; pp. 89-115.

69. Giménez, B.; Alemán, A.; Montero, P.; Gómez-Guillén, M.C. Antioxidant and Functional Properties of Gelatin Hydrolysates Obtained from Skin of Sole and Squid. Food Chem. 2009, 114, 976-983. [CrossRef]

(C) 2019 by the authors. Licensee MDPI, Basel, Switzerland. This article is an open access article distributed under the terms and conditions of the Creative Commons Attribution (CC BY) license (http://creativecommons.org/licenses/by/4.0/). 